\title{
Tropical Trolling
}

Two Tales of Trouble

$$
\text { by }
$$

Arthur StJohn Newberry 
Copyrighted 1911 by Arthur StJohn Newberry 
PRESENTED TO

BY THE WRITER 
ONE HUNDRED COPIES OF THIS

PAMPHLET HAVE BEEN PRINTED.

THIS COPY IS NUMBER 69 


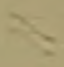

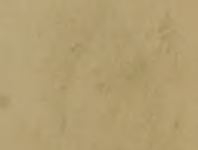




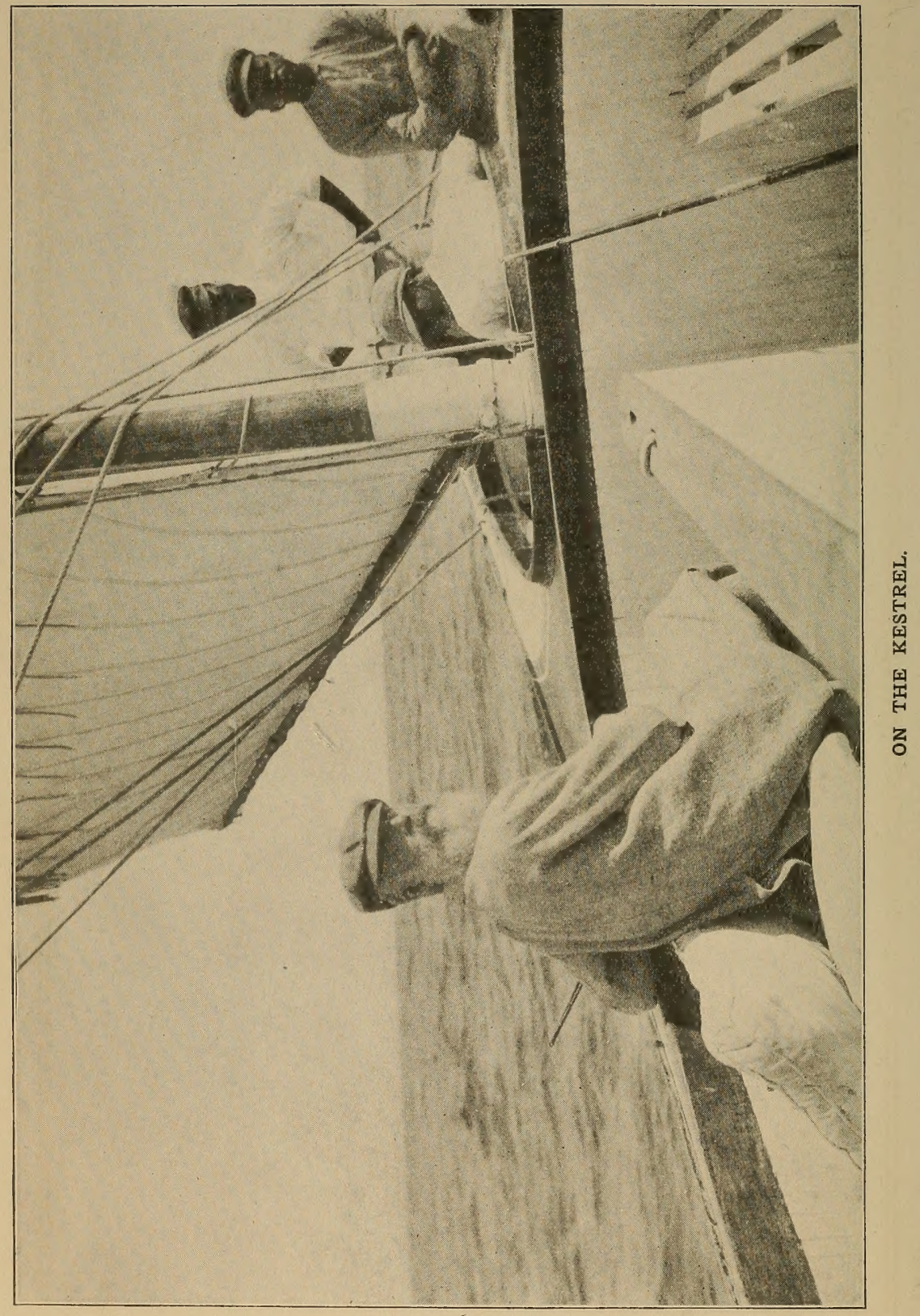




\section{Tropical Trolling}

Two Tales of Trouble

by

Arthur StJohn Newberry

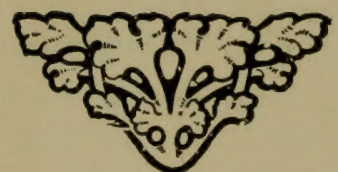

Printed for the $W$ riler by

The J. B. Savage Company

Cleveland, Ohio, 191/ 


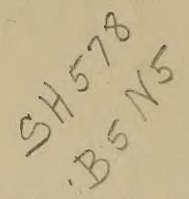

\section{To My Wife \\ A Very Present Help \\ in Trouble}

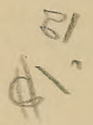

(C) Cl.A293798 


\section{ON LINES}

The line required for trolling with the rod, for the great game fishes of the tropical seas, must be a marvel of strength, lightness and endurance. The strain of taking a tuna or tarpon of a hundred and fifty pounds, even from a small and handy power boat, which can follow the fish and ease the tackle with the engine, is enormous. That put upon the line in taking a fifty-pound kingfish or amberjack, from a large sail boat, which cannot follow the fish and requires the whole work to be done with rod and reel, is probably equally great. In either case two or three hundred yards must be wound on a reel of reasonable size, and salt water soon attacks the fibre and causes it to rot, so that its life cannot be very long. A high class linen line should have a breaking stress of at least two pounds per thread, and maintain this strength for some weeks.

The spin of the bait in trolling has a tendency to untwist all cable laid lines and cause them to kink. One so untwisted and kinked must have weak spots, and be liable to break at much less than the strain that one, properly twisted and unkinked, will easily endure. For such fishing a line must have the minimum tendency to unravel and kink to do good service; it should also be dark in color, as a light colored line, in the wonderfully clear waters of the tropics, is too noticeable, and will according to my experience obtain much fewer strikes than one that is green or brown. I am satisfied also that the coloring matter lessens the tendency to untwist and kink and, to a considerable degree, protects from the rotting effect of salt water and so prolongs the life of the line.

The catalogues recommend that one should "set" his lines before use. This process consists in taking one off the spool, winding it on a stick in kite string fashion, so that it can be readily soaked, thoroughly soaking it, stretching it on a frame, permitting it to dry thoroughly, and then winding it upon the reel. Now the time and trouble required to so prepare two hundred yards of line is very great. I have found that to "set" three such lines required a night's soaking, followed by at least a whole morning's troublesome and annoying labor, as the stretching, drying, and reeling up can only be done by day and in direct sunlight. A slight shower, or the damp 
night air, will undo most of your work, which must then be done over again. Now I, at least, want to fish in my mornings and not to prepare tackle, and it seems to me manifest that all such preparatory work should be done by the maker or dealer, and that the fisherman should be able to buy a line completely ready for use. For such no reasonable sportsman would hesitate to pay an extra price, which would reimburse the maker for the extra labor and pay him a good profit besides.

The books also say that all lines used for salt water fishing should be taken from the reel each night, thoroughly washed in fresh water, allowed to dry completely, and then be replaced. Has any one of these writers tried it and found out how much labor this operation requires, how the lines will snarl, and how much time, which should be devoted to fishing, one must expend on this soul-destroying occupation? Let him attempt what he so cheerfully recommends to others, and he will know more and talk less. Of course rich men can hire others to do the setting, washing, drying and replacing, though it will be done less well than the fisherman would do it himself, but my experience has shown the whole process to be unnecessary, provided honestly made lines are furnished for one's money.

Six years ago I spent a month cruising among the Florida Keys, fishing near the reef for the great kingfish, amberjack, barracuda and groupers. Five years ago I spent nearly five months of the winter and early spring in Nassau, fished about eight hours a day, from a thirty-five foot sail boat, and took kingfish up to fifty-five pounds and amberjack up to fifty-two. I then could buy green or brown linen cable laid tarpon lines of two hundred yards each, of twenty-one or twenty-four threads, put them on my reels without any "setting," never wash or dry them, and find them give excellent service for about thirty days, with little tendency to untwist or kink. After that time it proved wise to replace them by new ones and this became my regular practice. In these two winters, at Nassau and in Florida, my line broke only once, and this was when I had neglected to exchange it for a new one after thirty days service, and perhaps was rather careless also. I used but a single large swivel, and never found keel sinkers, or any similar device, necessary to prevent untwisting or kinking.

I had hoped to return to Nassan the following year and break my own record on kingfish, and for that purpose then bought four of "Hall's Special Tarpon" lines, but illness and the panic of 1907 pre- 


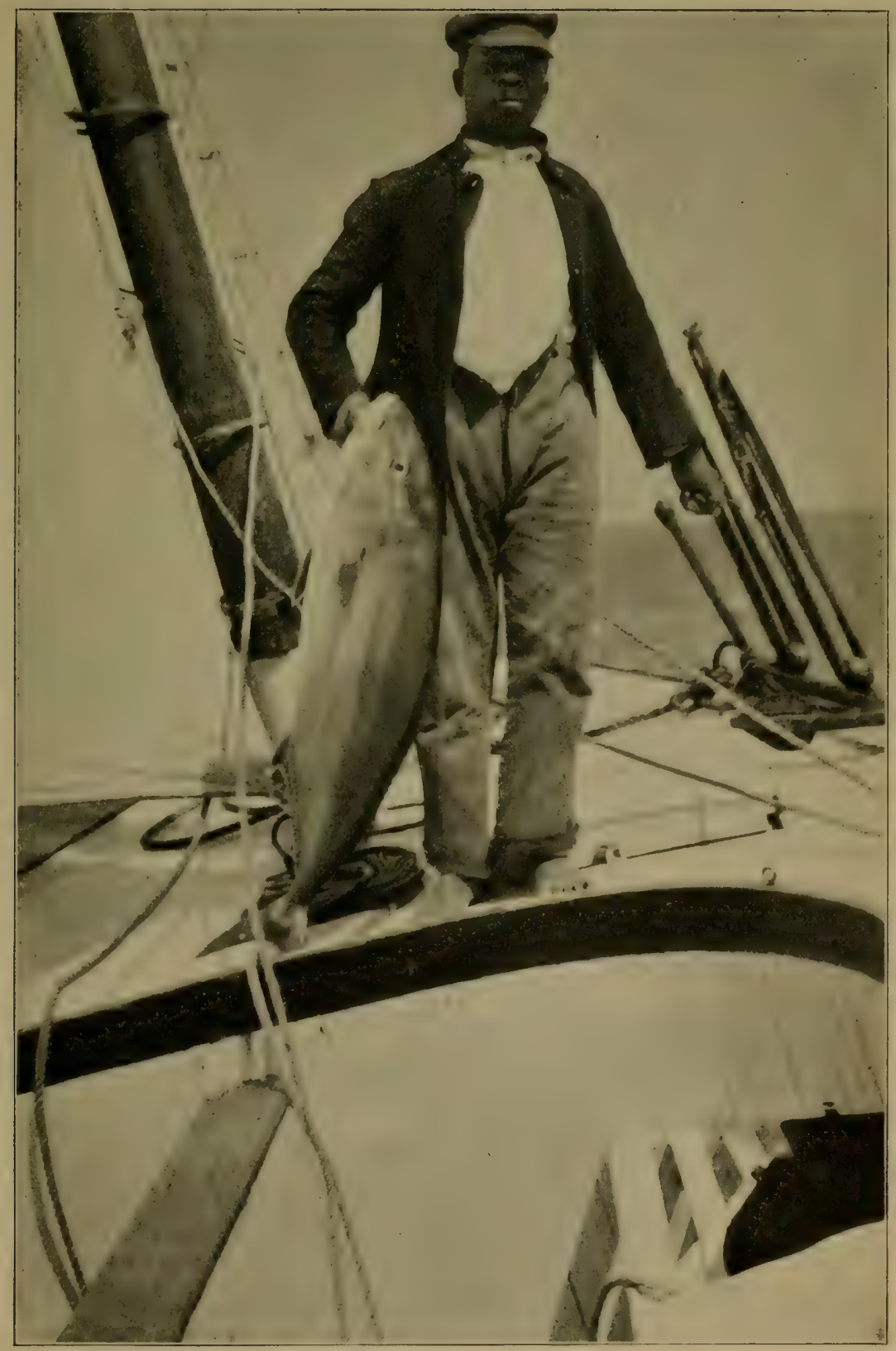

AMBERJACK-35 Pounds. 
it for two days more, reversing it each day, when it broke at the strike of a moderate sized fish. The second "unset" "Rex" broke about two hours after I put it on the reel. The other four "Rex" I "set" and found these give very varying results. One of them broke the first day I used it, the others lasted several days each, although it was necessary to reverse them every day, and in less than two weeks all of the six "Rex" lines were unfit for service.

The first "Gulf Tarpon Line," used "unset," encouraged me very much, giving good service for the first day. The next day I took off a "Rex," from one of my other reels and put a new "Gulf Tarpon" on it. This broke at the first strike I had. I then took off the "unset" lines and substituted "set" "Gulf Tarpon" lines. These gave better service than the "unset," but still untwisted, unraveled, kinked and broke. I reversed them every day and managed to catch some fish with them, but never could trust them.

Of the new lot of "Halls," received only a few days before leaving Nassau, I went through the process of "setting" one, and found that the soaking removed a very large part of the coloring matter. After careful setting and drying I used this line for two days with great caution, reversed it every night, and on the third day it broke at the strike of a moderate sized fish. I did not dare to use any of the other "Hall" lines, brought them back home with me, and returned them to the seller.

The best lines I had during the winter were two green tarpon lines, bearing the name "E. Vom Hofe," costing considerably less than any of the others, but even these were very far from good, enormously inferior to those of five years ago, unraveled and kinked badly, and broke frequently. Toward the end of my stay I always cut off the lower ten or twelve feet, after one day's use, always doubled the lower ten feet before using, watched very carefully for weak spots and, when one showed, cut it out and knotted the line, used keel sinkers and three large swivels, and yet continually got wretched service.

The big kingfish were very late in arriving this year, perhaps because the season was unusually cold, and all fish seemed very scarce, so up to April thirteenth, when I left Nassau, I had only hooked eight large ones. One was lost by the excitement of my skipper, one tore the hook out of its mouth, and six broke my lines short off, in spite of the very greatest care I could use.

During the whole winter I caught only one kingfish over twelve pounds, and this was three days before leaving. He was forty-eight 
inches long, weighed thirty pounds, and was hooked in the middle of the belly. Of course he made a most furious fight, repeatedly ran out nearly the whole two hundred yards, got under the boat, and was only kept from cutting off the line on the keel by plunging my rod straight down into the water. It took at least forty-five minutes to kill him. Every moment of this time I felt that the line was liable to fail me, and the fish was only landed by the greatest care.

I can only explain this disastrous and infuriating experience by supposing that manufacturers have been led, by competition or greed for greater profit, to use inferior material and labor, so that such abuses have arisen as, in another field of trade, the "Pure Food and Drugs Act" has done so much to remedy. The abominable notion, that the markets of the world are for the benefit of the producer and seller only, and that the consumer and buyer have no rights at all, which has done such grave harm in other industries, seems to have extended its baleful influence over the tackle trade also. Of course such an idea leads directly to fraud of all kinds, to the extortions of monopoly, the follies of the tariff, and countless kindred evils. These can be overcome only by informing and directing that Public Opinion, which is the court of last resort in this country, and the only method of successfully doing this is by Publicity, by throwing light into the dark places.

That thoroughly reliable lines can be made and sold, at a reasonable price, is conclusively shown by my experience of five years ago, and a dealer or maker who will furnish such trustworthy lines can have from me any reasonable price he asks. I want good lines, regardless of cost, and appeal to all my fellow sportsmen to help me find them, if they can be now had, and, if not, to join me in a crusade that will produce them. Let us all condemn, in print and giving full names of lines, maker and dealer, such tackle as we have found bad, and, in the same way praise such as we have found good. I am sure that the columns of all our papers devoted to sport will be open to us for this worthy purpose.

I have not written this article, nor do I propose the above suggested course to my brother fishermen, for the purpose of wreaking vengeance on any one, but want to use, and have other fishermen use, the great weapon of "publicity" for the protection of fishermen, honest dealers, and honest manufacturers, against dishonest manufacturers, who cheapen their product by using inferior material and labor, and dishonest dealers, who sell something they know to be inferior. Of 
course, the dealer may be also deceived, so a time limit might be allowed before dealers are denounced by name.

I have dealt with Messrs. Abercrombie \& Fitch for many years, and have found them most courteous and accommodating, and never until this winter have I got bad material from them. I wrote them fully, stating my experience. They expressed great regret and volunteered to take back all goods purchased from them, which proved unsatisfactory, and refund the full price, but this does not cover the case. If I buy a line for three dollars, and hook and lose a record fish through its failure, a refund of three dollars or a payment of three hundred dollars, or any money sum whatever, would not satisfy me. What fishermen want, especially those who are exercising their craft in distant regions, where no supplies can be had and communications are slow and uncertain, is tackle that can be depended upon and not a claim for damages.

I also wrote to the Simmons Hardware Company, of St. Louis, reporting the unsatisfactory results obtained with the goods bearing their name, but have not yet received even the courtesy of a reply.

I had other experience with unsatisfactory tackle and other trials on this trip, which really made it memorable for misfortune, and these I shall describe in a future article, but the present one is devoted to the subject of lines only.

The following seem to me established as conclusions:

1. The lines now made and sold for tropical trolling are enormously inferior to those obtained five years ago.

2. All linen lines should be sold "set" and ready to put on the reel, and fishermen should refuse to buy any others.

3. All linen lines, for salt water trolling in the tropics, should be dark colored, never white or natural color.

4. The cable laid linen line is, and must always be, unsuitable for trolling, on account of its tendency to untwist and kink.

A braided linen line, if of the best quality and made with the greatest care, might give much better service. Whether a braided line can be made of the same strength as a cable laid line, without much, if any, increase of size, I have no means of knowing and should like to be informed. If so I am ready and anxious to buy a lot of them.

Next year I shall again avoid the northern winter by going back to the tropics, and to where good fishing can be found, and do not 


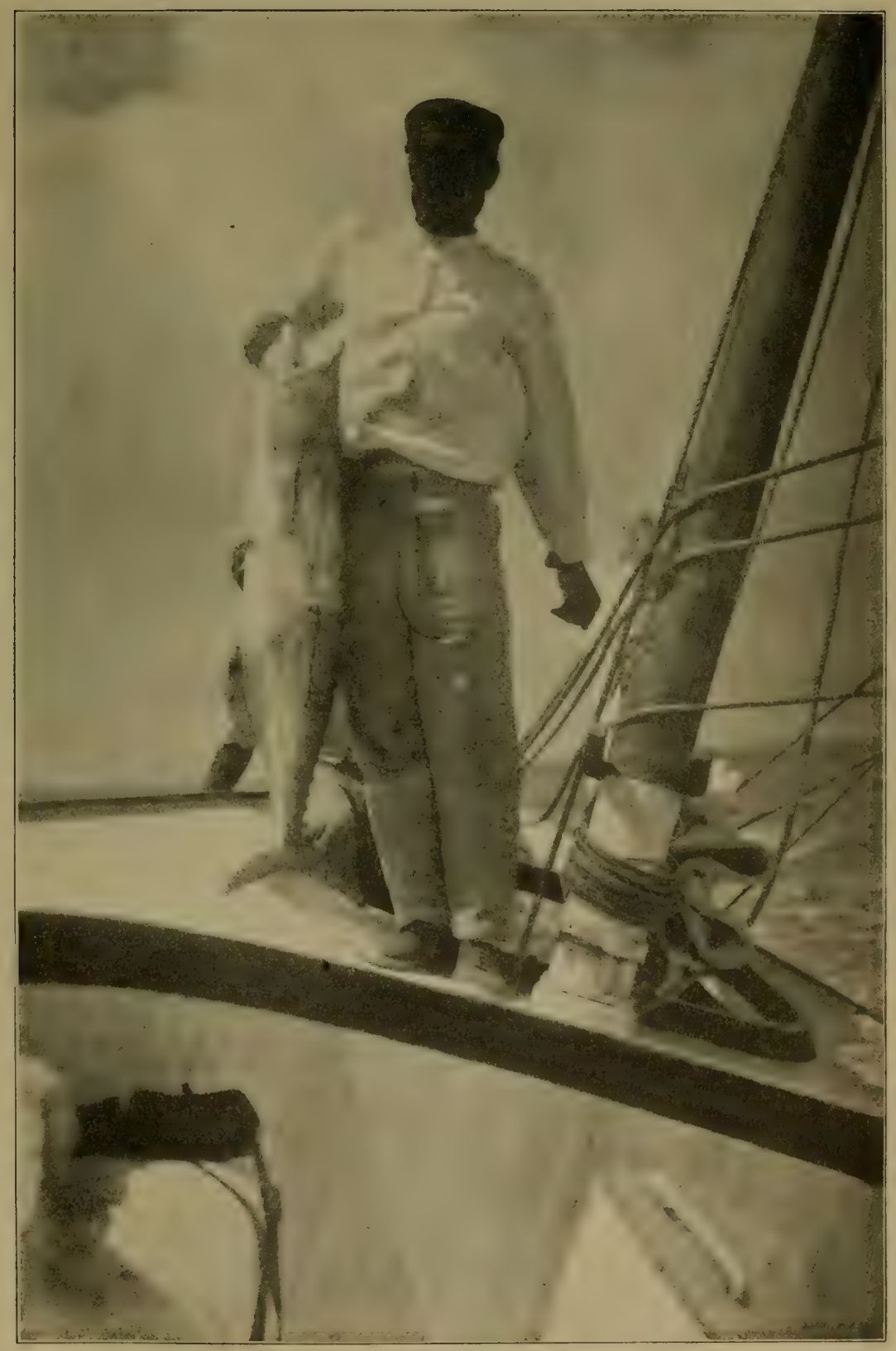

KINGFISH-30 Pounds. 



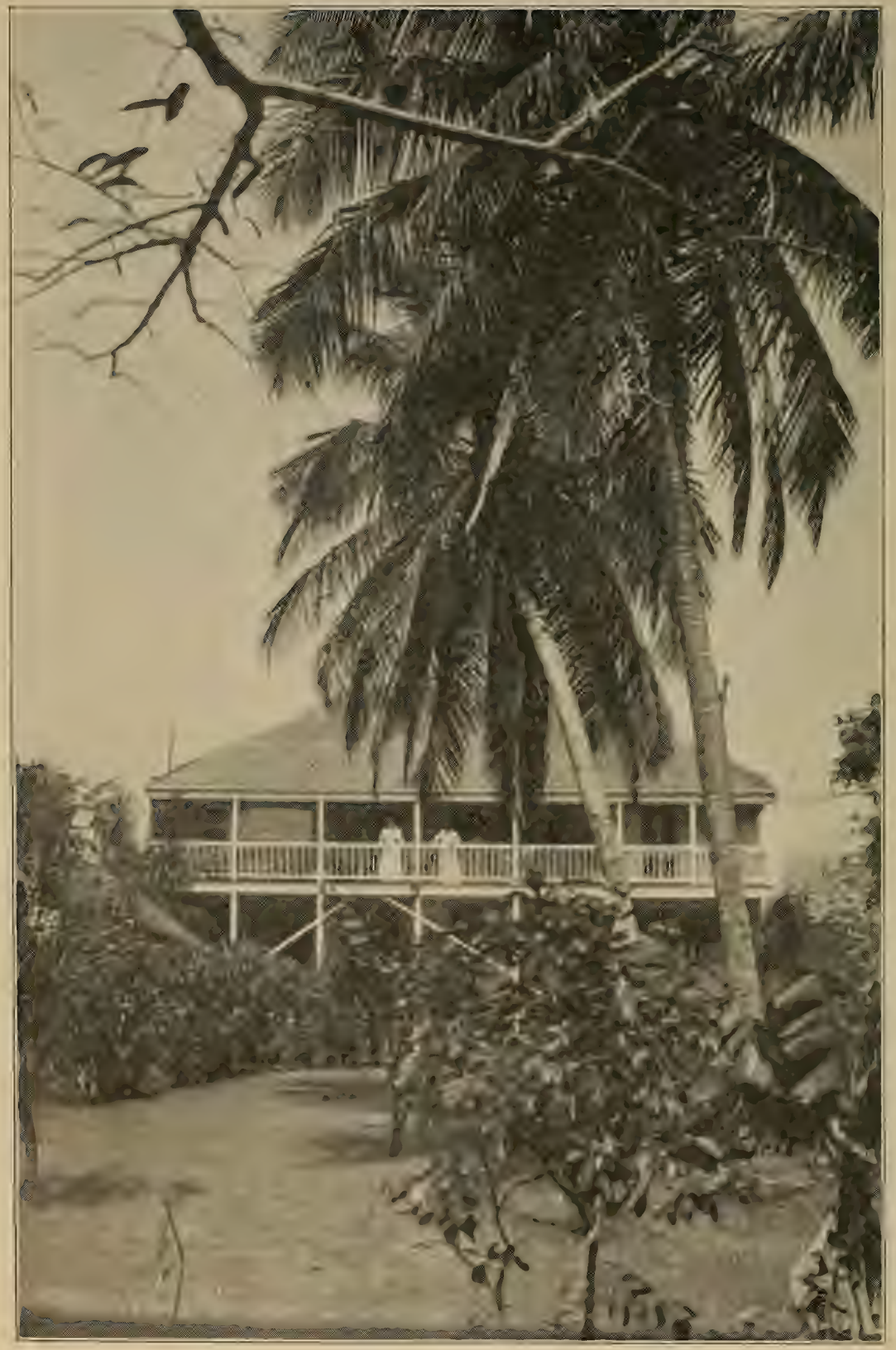

MY HOUSE AND GARDEN. 
want to waste the coming winter as the last one was wasted, so I appeal to my fellow sportsmen, and to all dealers in and makers of angling goods who have learned that a pleased customer is the best advertisement, to help me to find trustworthy tackle, and to aid their fishing friends, known and unknown, to avoid such an infuriating experience as that $I$ have just passed through.

Cleveland, Ohio, June 2\%th, 1911. 



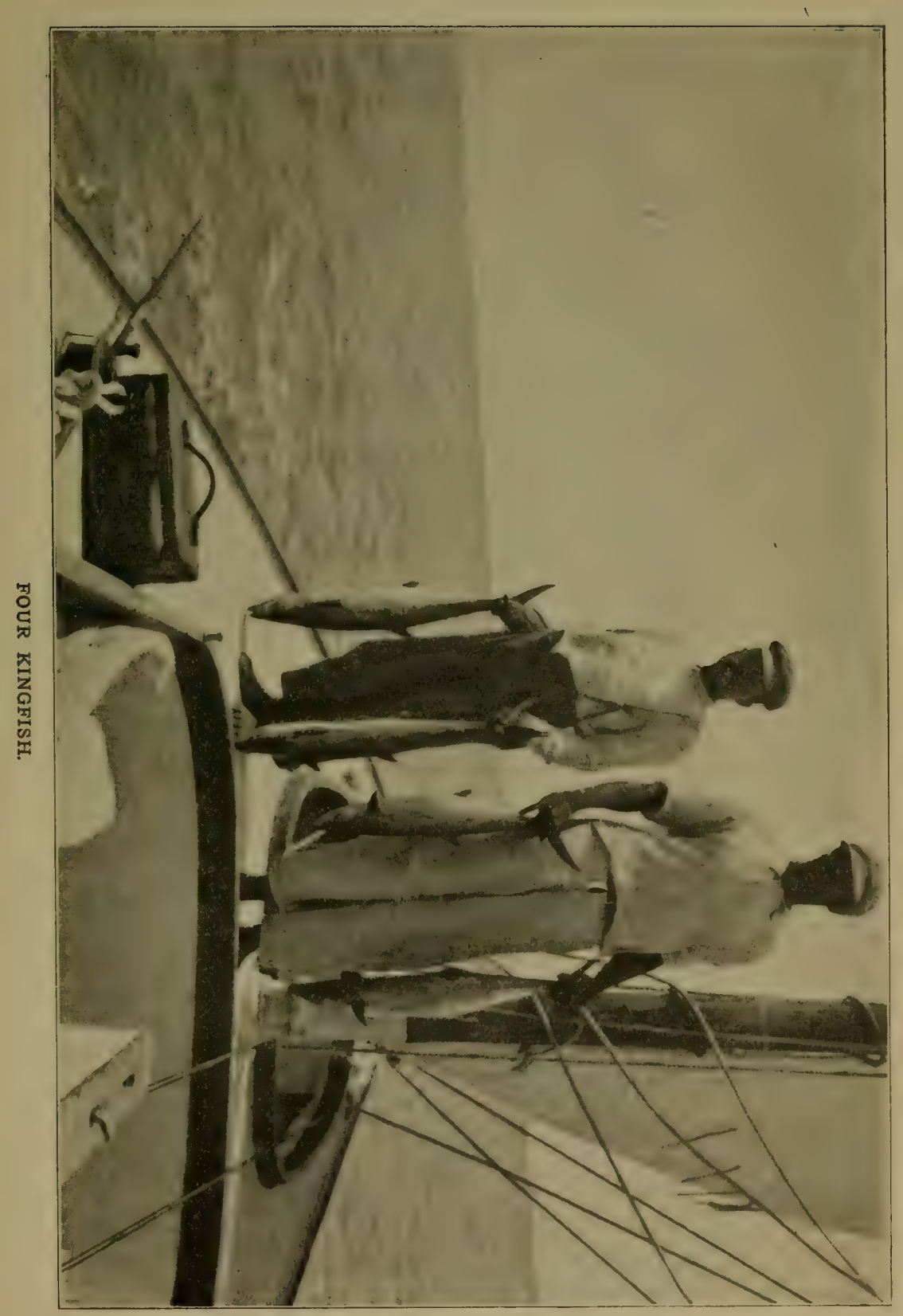





\section{TROUBLE IN THE TROPICS}

The winter of 1905-6 I spent in Nassau and found there a most picturesque island, a perfect climate, much natural and artificial beauty, much pleasant company and particularly good fishing, and the latter was described in the columns of Forest and Stream shortly after my return. My time was devoted chiefly to trolling for the great tropical game fish, kingfish, amberjack, barracuda, and others, using tarpon tackle and a thirty-five foot, two-masted, pilot boat named the "Kestrel." The winds were regular, so that the boat almost always traveled at sufficient speed, and calms or very high winds were infrequent. The sea was free from gulf weed, which when present in any quantity is a terrible nuisance. Bait could be readily procured and fish were plentiful. My lines, rods and reels also gave excellent service. I had a spacious and convenient house on a ridge overlooking the harbor, a garden full of grapefruit, oranges, cocoanut palms and roses, and altogether, both for comfort, convenience and sport, found it the most delightful place imaginable. When tired of trolling, one could anchor and catch plenty of the beautiful, strange and brilliantly colored fish of the tropics, so that the bottom of the boat after fishing looked like a flower garden.

Nassau seemed to me an ideal place to pass the winter, and I vowed never again to see a flake of snow if it could be helped, but rather serious illness prevented my returning the following year. Then came on the panic of $190 \%$, with the depression succeeding, when every business man had to devote all his time and energy to strictly necessary business. But at last such troubles settled themselves, health was largely restored, and I expected that one more winter in the tropics would make me absolutely well. I was fortunate enough to be able to again engage the house, boat and crew of my former year, and early in January started off with the happiest of anticipations.

We sailed into the harbor on a perfect, brilliant morning, over the turquoise, opal and sapphire water and, among the crowd swarming to meet the steamer, was my old Captain, John Darrow, who welcomed me with a most gratifying heartiness. We found the 
house completely ready for us and, through the great kindness of its owner, equipped with servants and supplies, so that we could settle down at once. It had been improved by the addition of mosquito screens, being the only house in Nassau so equipped, and a telephone and electric light, since our former visit. The trees in the garden were laden with grapefruit and oranges, the roses and hibiscus were in full bloom, and we at once felt completely at home again.

But this delightful beginning was succeeded by a series of vexations and annoyances so far unmatched in my experience. Nassau has an infertile soil and very little productive industry, so that wages are excessively low and it is often impossible for a laborer to get work at all. In the past five years these conditions have produced their inevitable result. Many of the best and most energetic of the population, both white and black, had emigrated to the United States, those engaged in any class of business were fewer and the most enterprising of them had already gone. The fishermen supplying the market were fewer than formerly, and perhaps they were less diligent and efficient also, the result being that the "goggle-eye," which small fish is generally used for bait, was scarcely and irregularly supplied, and it was often impossible to get them on days when everything else was favorable. After many annoying experiences of this kind I met this difficulty by arranging to get a supply of bait, whenever possible, and have it kept on ice, and such cold storage baits, while they were not quite so good as fresh ones, seemed to answer reasonably well.

When this difficulty was disposed of and I was able to go out regularly, fish proved to be much less plentiful than they had formerly been. Whether this was due to a rather unusually cold winter or to some other reason I cannot tell. The temperature never fell to much below seventy, even during the night, but tropical fish are extremely sensitive to cold and even a slight drop in temperature will drive them away or prevent their biting. I had been accustomed to find good sport just outside the mouth of the harbor and all along the shore for twenty miles or more, but this year there seemed to be no fish anywhere near the harbor's mouth and grounds, which had been most prolific in the former season, yielded nothing whatever to the most painstaking effort.

The winds, on which we depended entirely for propelling power, and which had been so steady five years ago, were also very variable and uncertain. On many days we were unable to fish because the 


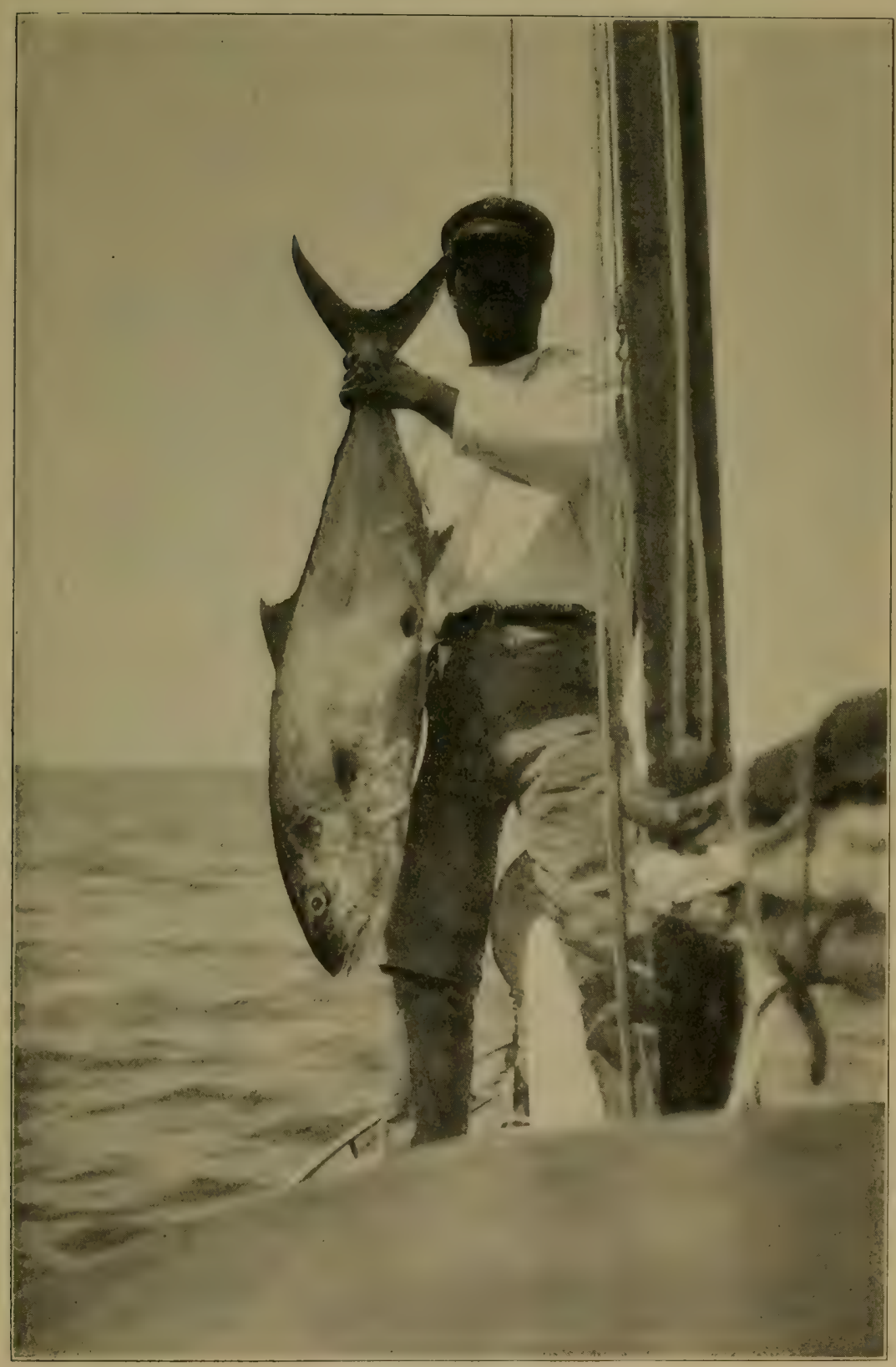

AMBERJACK - 43 Pounds. 

wind was too high and very frequently, after getting outside with a good breeze, it would drop away to little or nothing and our boat would float around in a calm, helpless and useless so far as fishing was concerned. When other troubles were not present, when I had bait, when the wind blew and when the fish seemed in biting humor, the yellow gulf weed would come down from the north, cover the sea with great masses of floating herbage, and one would pass most of his time in reeling up his long line, disentangling weed, and putting out again. Of course, a bait with a weed on it will not be touched by any self-respecting fish and to haul in and let out again a hundred yards of line takes a considerable amount of time, so that much of my fishing days would be wasted in this way.

All these difficulties arose from the caprices of Nature, and had to be endured, but unfortunately I also suffered from troubles which were the result of the carelessness, if not the dishonesty, of man. My tackle was selected with the greatest care, guided by the experience of past tropical fishing, and was supposed to be of the very best, but proved in many respects untrustworthy. The worst offenders in this respect were my lines, which broke, snarled, tangled, kinked, and committed every other sort of crime in a manner which was entirely beyond my experience. As I have elsewhere described this particular trouble, my grievances in this respect will not be repeated here, but this was far from the only defect in my outfit. Finding that my two large reels were not sufficient I ordered a new tarpon reel, fitted with a "rabbeth drag" and costing thirty dollars, from Ahercrombie \& Fitch, of New York. When this reel arrived it had no safety catch or pawl, to engage with the teeth on the central screw, which holds the drag upon the reel. The result of this was that, the instant a fish struck and began to whirl the friction disc, this central nut would loosen itself and, unless I kept constantly tightening it up with a screw driver or my fingers, would almost certainly come off and take the whole reel handle with it. It was inexcusable to send this reel with this old style friction plate, without a pawl on it, when the new style, with a pawl, are kept regularly in stock, but I wrote at once for a new style plate and tried to use the reel meanwhile. On the second day, while playing a good fish, the click broke short off, the broken part jammed the reel so that it could not be used and my fish was promptly lost. On investigation I found a very marked flaw in the click. The reel being now useless, had to be packed up and sent off north to be mended. It must be borne in mind that Nassau is 
about a thousand miles from New York, that all merchandise is sent by parcels post, and that steamers carrying parcels post packages leave New York only once in two weeks or so. Therefore, it must take more than a month to get this reel north, repaired and back to me, and I was in fact deprived of its use for nearly six weeks.

As a substitute for bait I had bought a number of the "Sam" spoons of large size, a spoon being serviceable and effective whenever the wind is reasonably strong and the motion of the boat rapid, and being in some ways preferable to bait, because it is not cut by the teeth of a fish striking and consequently does not have to be hauled in and renewed. The "Sam" was more lively and active in the water than any spoon I have ever seen, but developed three very grave faults. First; they tarnished so badly that, after a few hours' use, one had to scrub them with specially made scouring cloths for fifteen or twenty minutes in order to get them decently bright. Second; they were fitted with the "Van Vleck" hook, which has an incurved point. Whether on account of this or some other reason they did not fasten fish well, and I got a large number of strikes on these spoons without hooking the fish. Third; the ring of the hook, which fastened into a strong loop of metal on the spoon, proved altogether too weak. The hooks wore away very rapidly and, on at least two occasions, very heavy fish were lost through the breaking of hooks at this point.

Becoming disgusted with the unsatisfactory results of trolling, bottom fishing was tried. Fish seemed to be unusually scarce and, what I had never known before, sharks were unusually plenty. Going out for a day, after taking two or three fish one wasl likely to have his hooks bitten off by a shark, and could not escape these miserable brutes, either because they followed when ground was changed or because they were so numerous that there was always a new one handy. Bottom fishing, therefore, was in every way a failure and not worth the trouble it cost.

On one particular day I invited three ladies to go out with my wife and myself, expecting to fish for a while and then sail up to the end of the island, land, eat our iuncheon there, and have a pleasant sail back. The wind became so light that it took at least two hours to get to the fishing ground. Finally we got our lines down and took one or two porgies, when the usual shark arrived. I was using my tarpon rod and a twenty-four thread line with comparatively small hooks. After biting off one or two of other baits, the shark came to 
me, was hooked, played a while, straightened out my small hooks and departed. I then put on a steel wire leader with larger hooks, promptly hooked him again, and played him for some fifteen minutes, once bringing him up into view and seeing that he was about ten feet long. After having pretty thoroughly tired me out he bit my wire leader off and left. We then shifted our ground a half mile, but either this shark or another one promptly turned up and repeated the process. We gave up fishing as useless and tried to eat luncheon, but the boat wobbled round in the hot sun and uneasy swell, most uncomfortably, and all of my guests grew seasick. Finally I had to put the crew in our small boat, rig a tow line, and be ignominiously hauled about two miles into the harbor.

As may be readily seen, with the combination of all these difficulties, fishing for the first two months of my stay was generally unproductive. Going there with the especial purpose of beating my own record for kingfish, fifty-five pounds, in that time I caught very few kingfish at all and none over twelve pounds. During the last month the fish were more numerous and I did hook in all eight heavy kingfish. One of these escaped through the excitement of Captain John, who devoted himself to telling me how to fish instead of to managing his boat, one tore the hook out of his mouth, and six were lost by the breaking of my lines.

It should be said here that the play of the kingfish, especially one of any considerable size, is unmistakable. He strikes with a ferocious rush which may take a hundred yards or more off the reel, then he will become somewhat quiescent and can be reeled back part way toward the boat. Then comes another rush, and such rushes and periods of comparative inactivity succeed each other until he is brought near the side. When the fish first sees the boat there is invariably a tremendous rush. The fisherman must guard against this, by keeping his rod up and his line free, or something is practically sure to break. During the whole winter I took only one kingfish exceeding twelve pounds in weight, and this was a spotted kingfish, S. regalis, forty-eight inches long and weighing thirty pounds. In some strange way he was hooked just in front of the amal fin, naturally made a most tremendous fight, and was only gaffed after more than a half hour's play. His picture appears herewith.

Of course in so many days of effort I had to catch some kingfish, and one of the pictures accompanying this article shows the stern of the "Kestrel," with my crew holding up four that ran from seven 
to ten pounds each. At the left of the picture appears my rod, with the handle of the friction-clutch reel made fast by a loop of the jibsheet, the rod being stayed out overside by my tackle box. When busy with other matters I used to rig out the rod in this way. If a fish struck the motion of the boat would hook him, the click would sound an alarm, and one could slip the rod from its fastening and play him as usual. On the rail around the cockpit, on the left side, appears a little device of my, own, consisting of a large wire nail holding a spool against which the rod is rested. This relieves the left arm from the strain of trolling and is extremely useful, as that arm does practically all the work in playing a fish and should be kept unfatigued for that purpose. At the right of the cockpit are two extra rods, one of which has a new bait ready for use, should the other bait be struck and cut, and the second one is fitted with a large spoon, to be used in case the wind rises enough to give sufficient speed to make the spoon effective.

Big amberjack, most powerful of fishes, were not uncommon, and we took a number of these up to forty-three pounds, but the large amberjack, though a tremendously quick and powerful fish, is worthless after you catch him, being tough in flesh and also very likely to be poisonous, producing the very serious disease called "ciguatera." I have a theory that a really game fish must be shy and difficult to attract, powerful and active when hooked, beautiful to look at, and good to eat after you get him, and therefore that the amberjack and tarpon, which are tremendously strong and active but worthless or dangerous as food, do not strictly come within this category. As I have never caught a tarpon it may, however, seem presumptuous for me to express this view.

It was interesting to see how seriously the crew of the "Kestrel" took our bad fortune. These men had never seen any trolling with the rod until my first winter with them, and were at first extremely doubtful of the ability of the small lines to hold big fish. After some successes they became extremely contemptuous of those who trolled with big, white, hand lines, and certainly took as much or more satisfaction in every big fish brought in than I did myself. One of them would always take any especially large and fine capture on his head, and walk with it up the main streets of the town, where the most people were, being as proud of the attention he attracted as any child with a new suit of soldier clothes. 'Our persistent bad luck depressed them in equally great degree and they would almost weep when one 
disaster followed another. They were most excellent men, gave me the very best service that was in them, were capital sailors, and obliging, diligent and efficient to a very high degree. Of course, like all the West Indian negroes, they are to a certain extent like children and have to be treated as such, but are most appreciative of kindness and responsive to it. The life of these poor fellows is a pretty hard one. My captain, who is an unusually good man, told me that during the previous summer he went through four months without being able to obtain any work at all. One of my crew, who lived at Governor's Harbor, on one of the outer islands, from which nearly all the best negroes in Nassau come, had strained his back in unloading a vessel, his wife had been ill, two of his children had died, and I really do not see how the poor fellow had lived. When he came to me the signs of starvation were deeply marked on his face. My contract did not cover the feeding of my men but, on going out for all day, I always took lunch enough for them and for myself and, instead of carrying water, took a number of partly green cocoanuts, the liquid inside of which is always cool and refreshing. When a nut was emptied, poor Sweeten would say, "Will you please hand it here, Chief?" and make up some of his arrears of food from the creamy flesh inside. When I bade him goodbye he was fat and shiny, but I fear the future has some hard times for him and for them all.

One day we were down by North Key when it began to grow very black on the northern horizon. I got in the lines and started for the harbor, but had just crossed the bar when a tremendous squall struck us. We had no ground tackle but a rather light grapnel, which was sufficient for all ordinary purposes, but far from big enough to hold the boat against a very high wind. We got under a slight lee by the lighthouse point and anchored, but promptly began to drag. Then the crew hoisted the foresail double reefed, hauled in the grapnel, and tried to beat up the harbor, but with this small canvas the boat would not come about, so we had to anchor again just in front of the Colonial Hotel. The wind continued to increase until the waves in that sheltered harbor were running six feet high and two boats, which had been anchored near by, broke their moorings and went on the rocks a quarter of a mile west of us. Then the "Kestrel" began to drag her anchor, pulling it through the sand for a while, then bringing up when the fluke caught a point of rock. It seemed pretty certain that we would pile up on the rocks, where the other boats had gone, and, though there was no danger to us except that of a complete wet- 
ting, the boat would certainly be destroyed. I got down into the forehold and pulled the hatch shut, where, though very wet, it was quite comfortable out of the sweep of the wind, and there lay for an hour or more. Presently there was a shout and, putting my head out of the hatch I found a row boat, half full of water and manned by a couple of darkies. My crew had called to the shore and these men had put off, well up the harbor, come down with the run of the sea and wind and got alongside. We bailed out the boat as well as possible, I climbed into its stern, and we started off before the wind and sea toward the flat rocks on shore. There a dozen or so of friendly negroes waded into the water up to their waists, grabbed the boat, hauled her up on the flat rocks and I stepped out. Of course my first thought was for my crew, who were out in the boat, with no food, not much clothing and thoroughly wet, and without waiting to shift my drenched clothes I got word to the white owner of the boat to send them an anchor, with food and drink also at my expense. This imitation of a man came down to the harbor, looked out at his boat, concluded there was no hope of saving her, and did nothing whatever. My crew stayed on that boat without food and thoroughly chilled until three o'clock in the morning, when the gale moderated, they were able to land, and after getting dry clothes and a cup of coffee came over to tell me the story. Being pretty thoroughly indignant, I started out to find that man and tell him my opinion of him but, perhaps fortunately, could not then find him and my anger had time to cool down before I saw him again.

The bothers during this winter were not by any means confined to fishing. Photography has always been a pet occupation of mine, and during the last year I had taken up photographic portraiture and become greatly interested in it. My trunk contained a large kodak with an especially fine lens, a number of rolls of film, and a new metal tripod bought for use on this particular trip, the wooden ones not being trusted. This tripod broke a leg short off the first day it was. used. None can be got in Nassau, nor could it be repaired there, and over a month passed before it could be replaced by a new one from the north. Within the first ten days the shutter of my camera began to act badly and soon broke down entirely. So shutter and lens had to be taken off, sent north to be repaired, and were not returned to me for nearly six weeks. No films of the size necessary can be purchased in Nassau, and orders sent to the north seemed to meet with 


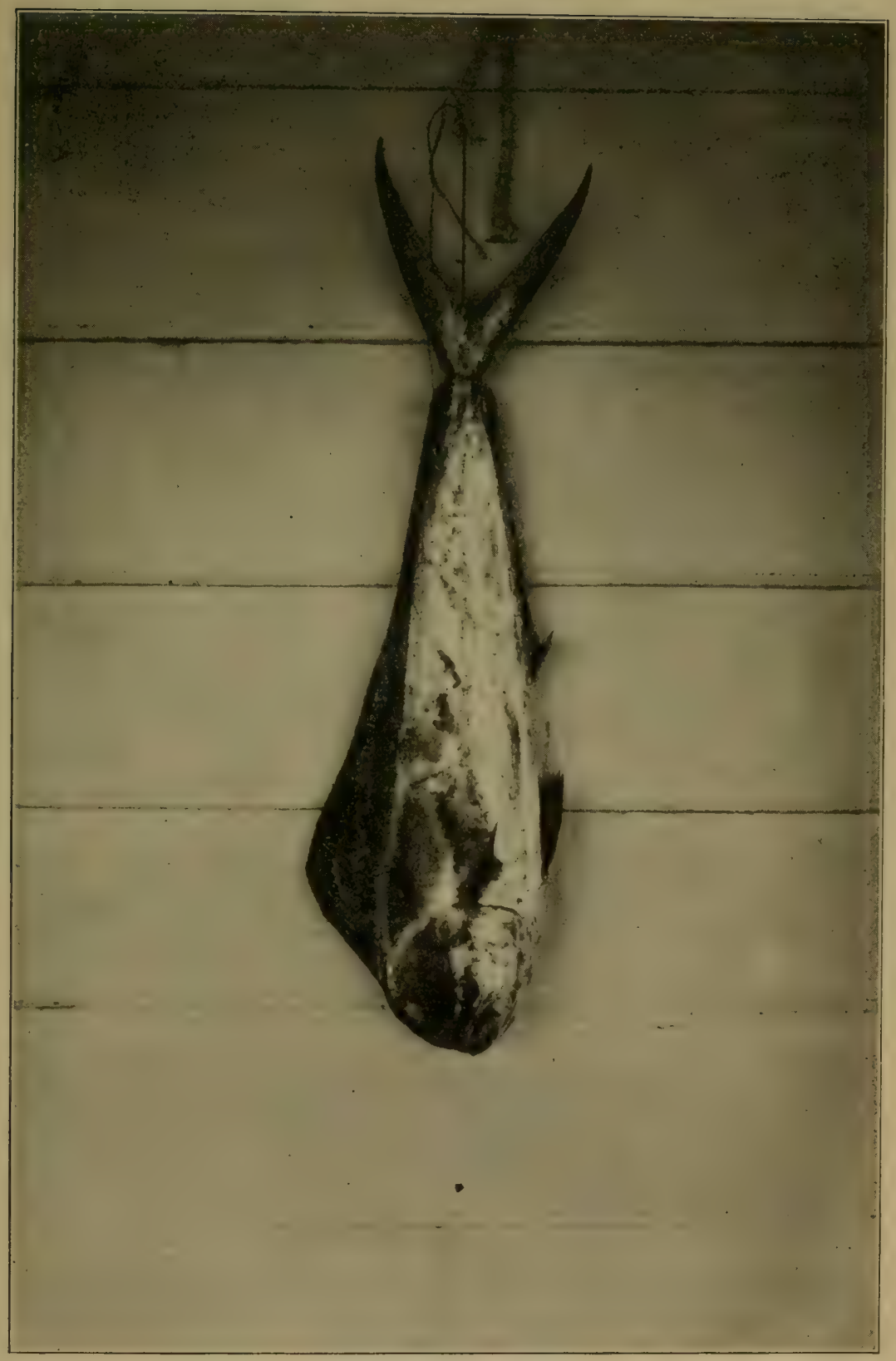

THE LITTLE DOLPHIN. 

very slow attention, so that much of the time this indispensable requisite was also deficient. My photography was, therefore, almost. as bad a failure as my fishing.

Having had experience with the ways of black servants, my wife took a maid down with her, who was to relieve her from the trouble of issuance of supplies, supervision of purchases and many other household duties. She was particularly faithful and coriscientious and we were all very fond of her. After having been in Nassau a few weeks she took to her bed with fever and weakness, which the doctor decided was due to tuberculosis. Instead of being of any assistance to my wife, the latter was obliged to nurse the girl continuously for over three weeks, until I grew very anxious for the effect on her own health. Fortunately, by the help of a resident physician, we were able to get passage for her on a comfortable steamer going north, under the care of a nurse who was traveling by the same vessel. All this we felt of course morally bound and even glad to do, but naturally we got no service from her and were put to heavy expense on her account.

So hard luck pursued me and mine throughout the whole winter, everything seeming to go wrong when there was the slightest opportunity to do so. Such continued worries and annoyances cause a nerve strain that cannot be beneficial to one's health, and the result was that I came home again far less well than when I went. So my winter in Nassau failed to fulfill my hopes in fishing, photograply, or health. This bad fortune continued until the very end, finishing with a railway wreck as we came west from New York.

It is very probable that, on going to Nassau another year, one would find none of the natural annoyances which I have described; but I intend to devote myself, and ask fishermen in general to join me in this, to preventing the recurrence of such troubles as come from defective tackle, by using the weapon of publicity. From now on I shall try to publish the names of everybody who sells me defective material, and also of those who sell me good and satisfactory stuff, and, if other fishermen will do the same, joining in a crusade for the protection of fishermen, honest dealers and honest manufacturers, against unscrupulous dealers and rascally manufacturers, who make and sell tackle that they know to be bad, such troubles cannot often recur.

Having given so long an account of my bad luck, let me now describe one of the few bright spots that lighted up the prevailing gloom. 
The dolphin, "coryphena," is a widely roaming fish, which may occasionally turn up in any part of the ocean, but is seldom found in any particular place. I had never hooked or caught one, nor seen a living one, although a friend once took at Nassau three small ones which he showed to me. The fish is very strangely shaped, the head being very large and the whole body thinning away toward the tail. The back fin runs nearly the whole length and is very high, and the tail is deeply forked, narrow in the blades and very wide. In color the fish is indescribably beatitiful. The great back fin is greenish purple with bright blue spots; the body varies from brilliant gold to old gold, profusely studded with large spots of the most brilliant blue, and the fins and tail are golden. These colors begin to fade as soon as the fish is dead and, within an hour, all brilliancy has disappeared and the fish shows only various shades of whitish, yellowish, brown and grey, the blue having practically all vanished.

As April came on the wind became especially light and uncertain, so that a sail boat was practically useless for trolling, and I was sometimes compelled to engage a motor boat to get any fishing at all. The first day this happened I invited a couple of guests to go with me. It was very rainy, dark and dismal, a most unusual thing, and we ran down nearly to the western point of the island without taking a single fish. On the way home, however, we ran into a school of small dolphin. One struck the hook, made a tremendous leap, at least six feet into the air and twenty feet long, and got away. Then one of my friends hooked another. Being entirely inexperienced in such fishing he was pretty nearly helpless, especially with such a ferociously active quarry on the end of his line. Seeing that he was making heavy work of it I said, "Do you want me to take your rod?" and he answered, "I wish to the Lord you would." So we made the exchange and, after twenty minutes of most active play, rushing, leaping and general cavorting, the fish came to gaff. My camera was not on board and, by the time the fish had reahed the house, the sun was down, but I hurried to get the camera, hung up the fish and took half a dozen pictures, varying the exposure on account of the uncertainty of the light. One of these gave a satisfactory negative, which is reproduced in this article. This picture was taken about three hours after the fish left the water and the colors are very dull. This particular dolphin was thirty-seven inches long and weighed fourteen pounds. I did not know its edible qualities, but had this one cooked 


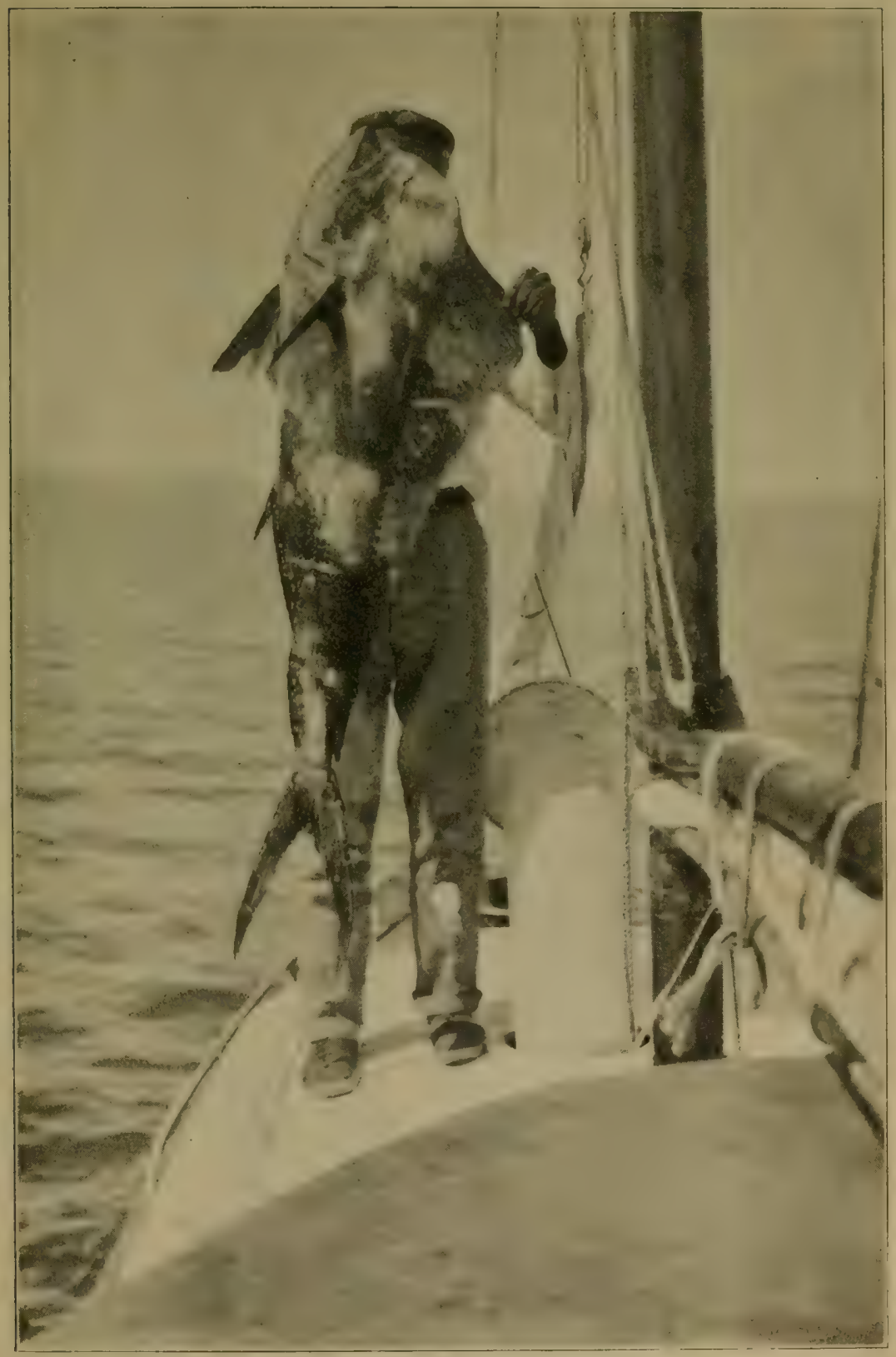

THE BIG DOLPHIN. 
and tried him. He proved most excellent, the flesh being finely flavored, tender and containing dark layers of high flavor very like those of a shad.

The last two days of my fishing I engaged another motor boat, somewhat smaller and a good deal handier than the first one. It had the grave objection that it was covered by a fixed roof, supported on stanchions, and this made it very difficult for the fisherman to handle his rod. Within half an hour after leaving the harbor something very heavy was hooked, which I hoped and prayed was my desired big kingfish, but which finally turned out to be a forty-three pound amberjack, whose picture is also reproduced herewith. This fish made a most tremendous fight and, as my line was already badly weakened and I had no confidence in it, it was necessary to use very great care and spend a great deal of time in playing him. Nothing else touched my bait for a considerable time, so we ran down to the westward until opposite North Key, about five miles from the mouth of the harbor. Here there was a lot of floating gulf weed, and, for fear of fouling it, I began to reel in my line. When twenty-five or thirty yards were still out there was a swirl in the water and Captain John called, "There's a dolphin after it!" I ran out a few feet of line, let my bait go back, saw the fish whirl up, snatch it and turn away, and struck him as one would a trout. The instant response was a tremendous leap in the air and I saw that he was a big fellow. Then began a most furious fight. He would run out my line almost to the end, leap six feet from the water (and he was a magnificent sight with the bright tropical sun on his brilliant color) then turn sideways, opposing his great width so that I could not recover any line at all. Then he swam in circles, our handy boat following him in the opposite way, so that we waltzed together over the bosom of the deep, and every now and then he jumped. I found it almost impossible to handle him, from my seat under the edge of the roof, which constantly interfered with the use of my rod, so kept a pull on him as well as possible, and scrambled out on the little stern deck, I holding hard to the fish and Captain John holding hard to me to prevent my going overboard. There I dropped into a sitting posture and had considerably more freedom, but the rudder chains ran along the top of this little deck and I had to sit on them, giving attention both to handling my fish and to easing up so that the rudder could be worked under me. It took at least three-quarters of an hour to kill that dolphin, but finally he came up closer and closer and, at last, Captain John jerked the big steel 
gaff into him and lugged him aboard. On that day I had the camera along, so instantly dropped my rod, got the camera out of its case, adjusted focus and stop, scrambled up on top of the house, and had Captain John stand up at the extreme end of the after-deck and hold the fish in the air. The resultant photograph printed herewith proved most satisfactory, showing the contrast of color so far as black and white can do it. Such a picture cart only be obtained by a remarkable combination of circumstances. The dolphin could not possibly be handled in an ordinary sail boat, so one must be a skilled fisherman, with proper tackle, in a motor boat, in the tropics, on a sunny day, provided with a camera and knowing how to use it, a big dolphin must come along, take the bait, he fought and landed, and be photographed as soon as he stops kicking. That all these things should happen together is not likely to occur twice, even if a man fishes diligently for a considerable number of years.

This particular dolphin was fifty-seven inches long, seventeen inches deep and weighed thirty-five pounds, which my captain says is about as large as they grow, but this may or may not be correct. His widely forked tail was one foot ten inches from tip to tip. I have never met the tarpon or the tuna, but in strength, agility, beauty and all other qualities that make up a game fish, the dolphin exceeds any that I know from experience.

Cleveland, Ohio, June 2\%th, 1911. 
AUG $26 \quad 1811$ 


\section{One copy del. to Cat. Div.}

AUG $26 \quad 1911$ 


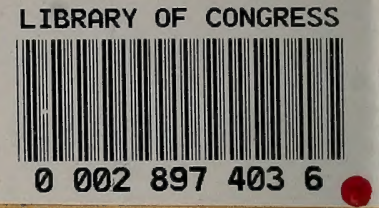

